\title{
Ecological cases of the ECtHR and the environmental risk of GMO
}

\author{
Elena Trikoz ${ }^{1,2, *}$ and Elena Gulyaeva ${ }^{3}$ \\ ${ }^{1}$ Moscow State Institute of International Relations (MGIMO University), Prospect Vernadskogo 76, \\ 119454, Moscow, Russia \\ ${ }^{2}$ Peoples' Friendship University of Russia (RUDN University), Miklukho-Maklaya str. 6, 117198, \\ Moscow, Russia \\ ${ }^{3}$ Diplomatic Academy of the Ministry of Foreign Affairs of Russia, ul. Ostozhenka, 53/2-1, 119021, \\ Moscow, Russia
}

\begin{abstract}
The aim of this article is to consider the guarantees of protection of such a fundamental human right of the fourth generation as the right to a healthy and quality environment. The authors focus on the Jurisprudence of the European Court of Human Rights (ECtHR) in environmental matters in cases. The article touches upon the States' positive obligations in particular the obligation to provide access to essential information enabling individuals to assess risks to their health. The research framework includes a discussion from a human rights perspective (the right to a healthy and quality environment). We consider the criterion of relevance (applicability) environmental cases where the pollution is directly caused by the state or when state responsibility arises from a failure to regulate adequately the private sector. Particular focus is placed on the category of Russian cases related to plants operation and above the norm air emissions as well as to the consequences of the Chernobyl nuclear power plant disaster. The article analyzes the EU policy regarding the regulation of production and turnover of products containing genetically modified organisms. With regard to environmental protection, the EU Charter of Fundamental Rights stipulates that a high level of environmental protection and environmental quality improvement should be integrated into EU policies and guaranteed in accordance with the principle of sustainable development. It was found that in the EU legislation and judicial practice on biotechnology and food safety, there is a rigid line of regulation of the production and circulation of products containing GMOs.
\end{abstract}

\section{Introduction}

At both the global and European scales the need to acknowledge a new fundamental human right, namely the right to a healthy and balanced environment is a relatively recent development. From a human rights perspective, the right to a healthy and quality

\footnotetext{
*Corresponding author: alena trikoz@mail.ru
} 
environment is a fundamental right whose nature and characteristics do not change over time. Although the Convention or its Additional Protocols do not have provisions directly related to the right to healthy and sustainable environment, the European Court of Human Rights in its jurisprudence and the European Commission case law data has recognized that certain types of environmental degradation with serious consequences for individuals or even the failure of public authorities to provide information on the environmental risks to individuals may constitute a violation of certain rights protected by the Convention provisions such as the right to life, prohibition of torture, the right to private and family life, or the right to property.

Speaking on October 24, 2020 at events to celebrate the 75th anniversary of the United Nations, UN Secretary-General Antonio Guterres noted that 2021 - 2030 has been declared the "decade of ecology" worldwide [1].

At present, principles related to sustainable development are most fully codified at the informal level in the draft Convention [2], established in 1995 by the Commission on Environmental Law of the IUCN in cooperation with the International Council on Environmental Law, and in the Declaration of Principles of International Law Relating to Sustainable Development, adopted at the ILA Conference on April 6, 2002.

It should be noted, however, that theorists classify environmental rights as the third and fourth human rights generation, in particular, the right to a healthy environment; the right to freely seek, receive, transfer, produce and disseminate information about the environment, legal phenomena and processes, etc. The fourth generation of rights often includes the rights of humanity - to peace, nuclear safety, peaceful exploration of outer space, environmental, etc. [3].

\section{Materials and methods}

The empirical basis was case materials of the ECHR, decisions of the International Court of Justice, extensive analytical materials of expert centres, international and national research organizations, scientific papers related to the issue under consideration. The authors analyzed materials from the European Court of Human Rights, the European Parliament, data from the World Bank, other institutions and organizations. It was necessary to use logical, formal-legal and a number of theoretical methods for observing the system approach. They include scientific methods of cognition, structural-functional analysis, and special legal and juridical-technical methods. In the context of the Bentham's utilitarianism and the R. Posner's juridical-economic teachings particular attention was paid to the use of the economic and legal method to the scope of environmental cases. Significant amount of material was obtained from the legal research services such as Consultant Plus, Garant, Westlaw Academics.

With regard to environmental protection, the European Charter of Fundamental Rights stipulates that a high level of environmental protection and environmental quality improvement should be integrated into EU policies and guaranteed in accordance with the principle of sustainable development. The European Court of Human Rights while hearing cases related to the protection of the right to an environment conducive to health and wellbeing relies on art. 2 (right to life), art. 3 (prohibition of torture) and art. 8 (right to respect for private and family life, inviolability of private property (Protocol No. 1 to the Convention).

\section{Discussion from a human rights perspective}

From a human rights perspective, the right to a healthy and quality environment is a fundamental right whose nature and characteristics do not change over time. Although the 
Convention [4] or its Additional Protocols do not have provisions directly related to the right to healthy and sustainable environment, the European Court of Human Rights in its jurisprudence and the European Commission case law data has recognized that certain types of environmental degradation with serious consequences for individuals or even the failure of public authorities to provide information on the environmental risks to individuals may constitute a violation of certain rights protected by the Convention provisions such as the right to life, prohibition of torture, the right to private and family life, or the right to property.

With regard to environmental protection, the European Charter of Fundamental Rights [5] stipulates that a high level of environmental protection and environmental quality improvement should be integrated into EU policies and guaranteed in accordance with the principle of sustainable development [6].

Among the 17 SDGs UN goals are environmental issues considered in Goals No. 3, 6, $12,13,14,15,16$, and 17. For example, "Goal 3: Good health and Well-being» - "Ensuring a healthy lifestyle and promoting well-being for all at any age" specifically, there is a need to reduce morbidity and mortality from hazardous chemicals and pollution (UN Sustainable Development Goals - 2030). It should be noted that the principle of sustainable development has become firmly embedded in the conceptual framework of international public law.

So, for example, in one of the decisions of the International Court of Justice of the United Nations, Judge K.G. Weeramantry, in a dissenting opinion to the decision in the Gabchikovo Nagymaroch case called it a new fundamental principle of modern international law (Case Concerning the Gabčíkovo-Nagymaros Project (Hungary/Slovakia) (1997), I.C.J. Rep. 7; the Legality of the Use by a State of Nuclear Weapons in Armed Conflict, Advisory Opinion, [1996] ICJ Rep. 226 at 438; Certain Phosphate Lands in Nauru (Nauru/Australia) (1993), I.C.J. Rep. 322; United States - Import Prohibition of Certain Shrimp and Shrimp Products, 20 September, 1999, WTO Doc. WT/DS58/AB/R (Appellate Body Report); LCB v. United Kingdom (1998), European Court of Human Rights Reports 1998-III).

The Sustainable Development Goals [7] are a call to action aimed at improving the well-being and protection of our planet. States recognize that measures to eradicate poverty must go hand in hand with efforts to combat climate change and protect the environment. The indicators are divided into major groups: indicators of social aspects of sustainable development; indicators of economic aspects of sustainable development; indicators of environmental aspects of sustainable development (including characteristics of water, land, atmosphere, other natural resources, as well as waste); indicators of institutional aspects of sustainable development (programming and policy planning, scientific developments, international legal instruments, information support, strengthening the role of key populations). Striving to become the first climate-neutral continent by 2050 under the European Green Deal, EU states are considering the possibility of adopting a European climate law aimed at referring political statements in terms or legal obligations and investment incentives.

In its jurisprudence, the European Court of Human Rights while considering cases related to the protection of the right to an environment favorable for health and well-being relies on article 2 (right to life) and article 8 (right to respect for private and family life, inviolability of the home) of the Convention for the Protection of Human Rights and Fundamental Freedoms of 1950 (hereinafter - the Convention, the ECHR). It is noted that article 8 of the Convention is used much more frequently (Application no. 36022/97, Hatton and Others v. the United Kingdom, ECHR Judgment of 08 of July 2003; Application no. 16798/90, López Ostra v. Spain, ECHR Judgment of 09 December 1994; Application no. 55723/00, Fadeyeva v. Russia, ECHR Judgment of 09 of June 2005). 
There is also little practice of applying article 2 - right to life (Application no. 14/1997/798/1001, L.C.B. v. The United Kingdom, ECHR Judgment of 9 June 1998; Application no. 48939/99, Öneryıldız v. Turkey, ECHR Judgment of 30 of November 2004; Applications nos. 67667/09, 44092/12 and 56717/12, Budayeva and Others v. Russia, ECHR Judgment of 20 of June 2017; Applications nos. 17423/05, 20534/05, 20678/05, 23263/05, 24283/05 and 35673/05, Kolyadenko and Others v. Russia, ECHR Judgment of 09 of July 2012) and article 3 - prohibition of torture (Application no. 36022/97, Hatton and Others v. the United Kingdom, ECHR Judgment of 08 of July 2003) of the Convention.

Environmental cases before the European Court of Human Rights are categorized as cases where poor environmental conditions are harmful to human health. As the Court notes in its jurisprudence, there is a close connection between the protection and preservation of the environment and the human right to health. Thus, the Convention does not cover an explicit established right to a clean and quiet environment. However, if human beings have been directly and seriously affected by environmental pollution, this may entail a violation of the rights enshrined in articles 2 - right to life, 3 - prohibition of torture or 8 - right to respect for private and family life of the Convention. A substantiated complaint shall be made if the environmental hazard reaches a level resulting in a significant restriction of the ability to live at home, infringes the right to privacy and family life (Application no. 16798/90, López Ostra v. Spain, ECHR Judgment of 09 December 1994, § 51).

The assessment of this minimum level is relative and depends on all the circumstances of the case such as the intensity and duration of the inconvenience, as well as its physical or mental impact on person's health or quality of life (Application no. 55723/00, Fadeyeva v. Russia, ECHR Judgment of 09 of June 2005, § 69). Article 8 applies to environmental cases where the pollution is directly caused by the state or when state responsibility arises from a failure to regulate adequately the private sector.

\section{States' positive obligations under the Enabling Environment Convention}

The Court's reliable principles for environmental cases are broadly similar. For instance, in terms of affirmative obligations, the state must take reasonable and appropriate measures to protect the rights of the applicants and in case of a public authority intervention. Both contexts must take into account the fair balance between the competing interests of the individual and society as a whole; and in both contexts, the State enjoys some discretion in determining the steps to be taken to ensure compliance with the Convention. Some cases in this area have been dealt with under art. 2 and a positive commitment to take all necessary measures to preserve life (L.C.B. v. The United Kingdom, ECHR Judgment of 9 June 1998, $\S 36)$.

In the context of hazardous activities, special attention is paid to the rules associated with the characteristics of the activity in question, especially with regard to the level of potential risk to life. The rules should regulate the licensing, establishment, operation, security and supervision of activities and mandatory implementation for all interested parties to ensure effective protection of citizens whose lives may be at imminent risk (Öneryıldız v. Turkey, ECHR Judgment of 30 of November 2004, § 90). Among preventive measures, particular attention should be paid to the public's right to information, as established by the European Court of Human Rights jurisprudence. Regulations should also provide for appropriate procedures, taking into account the technical aspects of the activity in question, to identify weaknesses in the relevant processes and any errors by the responsible persons at different levels (Budayeva and Others v. Russia, ECHR Judgment of 
20 of June 2017, $\S 132$ ). Where a State is required to take positive steps, the choice of means is, in principle, within its discretion.

So, in the case "Lopez Ostra v. Spain" about pollution caused by noise and smells from a recycling plant the ECtHR stated in 1995 that "significant pollution of the environment can have an impact on the well-being of individuals and prevent them from using their dwellings in such a way that it can adversely affect their private and family life, nevertheless, without creating a serious threat to their health "and made on the basis of Art. 8 of the Convention, a decision obliging the Spanish authorities to pay four million pesetas to the applicant in damages (ECHR Judgment of 09 December 1994, § 51). Art. 8 of the European Convention on Human Rights which states that everyone has the right to respect for his private and family life, the inviolability of his home and the privacy of correspondence was also applied by the European Court in 2006 in the case "Giacomelli v. Italy" which concerned a plant for storage and reprocessing of toxic industrial waste (ECHR Judgment of 02 of November 2006).

The Court held that "infringement of the right to inviolability of the home are not limited to specific or physical violations, such as trespassing but also include violations that are not specific or physical such as6

- noise (Bor v. Hungary, ECHR Judgment of 18 of September 2013; Yevgeniy Dmitriyev v. Russia, ECHR Judgment of 1 of December 2020),

- pollution from industrial activities (López Ostra v. Spain, ECHR Judgment of 09 December 1994; Fadeyeva v. Russia, ECHR Judgment of 09 of June 2005; Ledyayeva, Dobrokhotova, Zolotareva and Romashina v. Russia, ECHR Judgment of 26 of October 2006; Dubetskaya and Others v. Ukraine, ECHR Judgment of 10 February 2011),

- environmental accidents (Guerra and Others v. Italy, ECHR Judgment of 19 of February 1998; Tătar v. Romania, ECHR Judgment of 27 of January 2009; Öneryıldız v. Turkey, ECHR Judgment of 30 of November 2004; Budayeva and Others v. Russia, ECHR Judgment of 20 of June 2017),

- nuclear tests (McGinley \& Egan v. the United Kingdom, ECHR Judgment of 09 of June 1998; L.C.B. v. The United Kingdom, ECHR Judgment of 9 June 1998; Roche v. The United Kingdom, ECHR Judgment of 19 of October 2005),

- waste pollution (Brânduşe v. Romania, ECHR Judgment of 27 October 2015; Di Sarno and Others v. Italy, ECHR Judgment of 10 of January 2012; Giacomelli v. Italy, ECHR Judgment of 02 of November 2006),

- odors or other types of interference (Moreno Gómez v. Spain, ECHR Judgment of 16 of November 2004; Oluić v. Croatia, ECHR Judgment of 20 of August 2010; Mileva and Others v. Bulgaria, ECHR Judgment of 25 of February 2011; Zammit Maempel and Others v. Malta, ECHR Judgment of 10 of October 2017).

A serious infringement may result from the violation of a person's right to the inviolability of his home if it prevents him from using the amenities of his home and art. 8 of the Convention can be applied in environmental cases if pollution is directly caused by the State or if the State responsibility arises from the failure to properly regulate private activities.

It is rather remarkable that, in the case of "Giacomelli v. Italy" (ECHR Judgment of 02 of November 2006), the Court generalized some of its previous judgments based on Art. 8 on the environment: in the case "Powell and Rainer v. United Kingdom" (ECHR Judgment of 21 of February of 1990) the European Court of Human Rights declared art. 8 of the Convention is applicable because it considered that the quality of applicant's private life and the limits of the dwelling amenities were disturbed by the noise generated by the planes used by Heathrow Airport. 
In the case "Guerra and Others v. Italy" (ECHR Judgment of 19 of February 1998), the ECtHR noted that "the direct impact of toxic emissions on the claimants' right to respect for their private and family life means that Article 8 of the Convention is applicable".

We would like to take up the decisions of the Court on "ecological" cases against Russia. Key political documents defining priorities, goals, objectives and mechanisms for their achievement on the economic, social and environmental components of sustainable development, covering the areas of sustainable development goals of the 2030 Agenda. The environmental doctrine of the Russian Federation was approved by the Order of the Government of the Russian Federation dated by August 31, 2002 No. 1225-r. The strategic goal of state policy in the field of ecology is the preservation of natural systems, maintaining their integrity and life-supporting functions for the sustainable development of society, improving the quality of life, improving the health of the population and the demographic situation, and ensuring the country's environmental safety [8].

They were mainly related to plants operation (Fadeyeva v. Russia, Judgment of ECHR of 09 of June 2005) and above the norm air emissions (Ledyayeva, Dobrokhotova, Zolotareva and Romashina v. Russia, ECHR Judgment of 26 of October 2006) as well as to the consequences of the Chernobyl nuclear power plant disaster.

In the case "Fadeeva v. Russia" the complainant alleged violations of Art. 8 of the Convention since she lived about 450 meters from the largest steel plant in Russia and the plant pollution caused serious damage to her health and well-being. The European Court concluded that for a considerable period of time the concentration of various toxic elements in the air near the applicant's house significantly exceeded the established norms, the court found a violation of Article 8 of the Convention and ordered Russia to pay 6000 euros of compensation.

In the case "Dubetskaya and others v. Ukraine" (ECHR Judgment of 10 February 2011), in which the applicants were 11 citizens it was noted that "the right guaranteed by art. 8 of the Convention suffered ... as a result of environmental pollution caused by a state-owned mine and factory (in particular, their wastes), as well as the failure of the state to fulfill its positive obligation to ensure the safety of industrial activities that pose a threat. In 2002, the European Court of Human Rights ruled on the application of art. 2 of the Conventions in the case "Öneryildiz v. Turkey" (ECHR Judgment of 30 of November 2004). The claimant asserted that because of the authorities' negligence a methane explosion at the landfill on 28 April 1993 killed nine members of his family. The court considered the case under art. 2 of the Convention as a violation of the right to life, resulting from the failure of public authorities to comply with the obligations provided for by the Law on Environmental Protection and the Regulation on Solid Waste, which caused the subsequent explosion of ten houses and heavy loss of human life.

In 2002, the ECHR considered Mr. Burdov's complaint (Burdov v. Russia, ECHR Judgment of 7 May 2002) who did not directly allege a violation of art. 8 of the Convention but the case is clearly linked to the right to a favorable environment. The applicant was a Chernobyl "liquidator" where he was forcibly taken as a soldier and suffered from overexposure to radiation. He pursues the case in the European Court of Human Rights claiming that the decisions of the Russian courts granting him fair compensation were not enforced for an unreasonably long period (1997 - 2001). The judges unanimously found a violation of the right to a fair trial and ordered EUR 3,000 compensation. It recommended that the Russian Federation revise laws that are not in conformity with the international conventions it has signed and pay money to the Chernobyl liquidators without citing a lack of funds.

The decision issued by the European Court of Human Rights on "Malinowski v. Russia" (ECHR Judgment of 7 July 2005) in 2005 also merits attention. The applicant complained about the prolonged execution of the Russian court's decision. In Malinowski 
case housing was not provided for a long time contrary even to domestic law (specifically the Act of the Russian Federation "On social protection of citizens exposed to radiation as a result of the disaster at the Chernobyl nuclear power plant", under which social housing is provided to victims of the consequences of the Chernobyl accident within 3 months from the date of application). In fact, from 1999 to 2004 the applicant and his family lived in an apartment with inadequate living conditions. In 2001, the ECHR recognized Mr. Malinowski's right to an apartment but he didn't get a warrant until 2004. As a result, the Court as in the case of A.T. Burdov found a violation of art. 6 of the Convention and awarded EUR 3,000 compensation.

Precedents cited only indirectly affect the right to a healthy environment: the claimants were persons who suffered from the adverse effects of radiation, but their claims were caused by a violation of the right to a fair trial (Article 6 of the ECtHR), which also includes its promptness (Androsov v. Russia, ECHR Judgment of 6 of October 2005; Finkov v. Russia, ECHR Judgment of 8 of October 2009). It can be said that such decisions of the ECtHR encourage Russia and other states to comply with the internal compensational rules for damage caused by unfavorable environmental conditions within a reasonable time.

An issue of relevance to Russian cities was raised in the case "Grimkovskaya v. Ukraine" (ECHR Judgment of 21 July 2011). This process has created a significant precedent that can potentially be used by Russian citizens. The applicant invoking a violation of Article 8 of the Convention referred in the complaint to the noise, vibration and pollution of the environment caused by the traffic on the motorway adjacent to her house. Accounts obtained from the victim as confirmed by the results of inspections described the exposure levels several times higher than acceptable. Health problems have been developed. The vibrations were destroying her home. In its decision in favor of the complainant, the ECtHR noted the lack of sufficient measures on the part of the state authorities to control and reduce pollution. Attention was also drawn to the lack of adequate information for citizens in advance of the road construction and the lack of access and participation of citizens in the motorway planning. The ECtHR upheld the complaint by awarding compensation for non-pecuniary damage but pointed out, however, that the emphasis in the judgment was mainly on irregularities in decision-making and project implementation and not on the consequences and how to fix them. Therefore, the fact that the State did not provide the complainant with new housing and did not compensate for pecuniary damage cannot be considered as a violation of Article 8 .

\section{The environmental risk of genetically modified organisms}

Food and environmental issues are the joint responsibility of the EU and the Member States. The EU environmental policy on GMO crops integrates production and consumption policies, calls for the adoption of new product technologies and circulation instructions, excludes potential environmental risks of GMO production.

The European Union remains, along with the United States, the main center of policymaking for GMO market regulation and products sustainability. With the scaled-up scientific knowledge of biotechnology the system of regulation of production and GMO products turnover is changing substantially in the EU. The field of genetic research and genomic modification of living organisms and plant genetics is the area with the most "stringent" legislation (including countries like Norway, Iceland and Switzerland). Nonetheless, GMOs continue to be used in agriculture, food and consumer goods in the region. In Europe, any product containing more than $0.9 \%$ approved GMOs (which are very few) is considered to be genetically modified, or $0.5 \%$ for those still pending approval. Therefore, such products shall be notified accordingly on the package about their genetically modified nature [9]. In contrast to the USA, Canada and Argentina, where 
labeling is required only when a significant change in product quality or there is a health risk (allergies) [10].

Most EU member states have adopted comprehensive legislation to regulate issues such as GMO licensing, GMO product circulation, genetic safety requirements for plants and living organisms. Spain and Portugal being more permissive of GMOs than France and the Nordic population.

Moreover, the conventional (supranational) level of regulation and the ideological level of development of bio-communitarian policies in the region are also in progress [11]. The 1997 Council of Europe Convention on the Protection of Human Rights and Dignity of the Human Being with regard to the Application of Biology and Medicine (ETS No. 164) first raised biosafety issues related to genetic manipulation at such a high level including for medical and research purposes. ... This Convention has provided the ECHR with advisory judicial jurisdiction in order to protect the so-called "fourth generation of human rights".

The European Union has de facto the world's most stringent legislation and restrictions on GMOs [12]. We list the most important EU legal instruments in this area, such as: Directive 2001/18/EC on the deliberate release of GMOs into the environment; Regulation (EC) 1829/2003 on genetically modified food and feed; Directive (EU) 2015/412 amending Directive 2001/18/EC as regards the possibility for the Member States to restrict or prohibit the cultivation of GMOs in their territory; Regulation (EC) 1830/2003 concerning the traceability and labeling of genetically modified organisms and the traceability of food and feed products produced from genetically modified organisms; Directive 2009/41/EC on contained use of genetically modified micro-organisms; and Regulation (EC) 1946/2003 on transboundary movements of GMOs. The Commission Directive (EU) 2018/350 of 8 March 2018 amending Directive 2001/18/EC of the European Parliament and of the Council as regards the environmental risk assessment of genetically modified organisms.

So, according to the GMO definition in the Directive 2001/18/EC stipulates that foreign DNA needs to be present in an organism for it to qualify as a genetically modified organism. Organisms that thus have the foreign DNA removed do not qualify as GMO's, even if gene editing has been used to make the organism [13]. Of interest is the unified instrument based on Regulation (EC) 1829/2003. This document is considered to be the main one for regulating the production and trafficking of GMO products in the European Union, taking into account WTO norms and rules and the requirements of the Cartagena Protocol on Biological Safety of 2000. It is contingent upon favorable EU-wide market acceptance decisions for GMOs.

In general, the pan-European eco-regulation assumes that all GMOs are recognized as "new food products". The European Food Safety Authority (EFSA) conducts a comprehensive, individualized and scientifically maintained food assessment based on four broad categories: "safety", "freedom of choice", "labeling" and "traceability". In addition, the European Parliament's Committee on the Environmental, Public Health, and Consumer Protection approved "the safety first" standard for GMOs, which entails liability for any adverse health effects from GMOs.

Let us also refer to the ECtHR judgment of 29.06.2010 in the case of Hubert Caron and Others v. France (application no. 48629/08). The landmark decision of 25 July 2018 is known in the practice of the European Court of Justice in Luxembourg (European Court of Justice). It requires EU food suppliers working with genetic engineering technologies to strictly adhere to the Union's standards for the use of GMOs in the food industry. The case examined the practice of using the technology of artificial mutagenesis, which is based on the artificial modification of the structure of plant DNA and the removal of a number of its sections. This is being done to improve biological performance and yield. The first to alarm and sue were representatives of the French Union of Agricultural Producers who became concerned about the side effects of mutagenesis on humans, animals and the environment. 
But now, as the ECJ has ruled, all farmers who will distribute such products obtained using mutagenesis must label them as GMO products.

But at the same time there is another important "precautionary principle" proclaimed in the ECJ decision of September 13, 2017. The final verdict stated that cultivation of GMO products only be prohibited if there is strong scientific evidence of their harm to human health. In this case the Italian government and the American corporation "Monsanto", which grew genetically modified corn, initially clashed. This product has been identified by Italian scientists as hazardous to human health. At the same time the European Food Safety Authority issued another opinion that no scientific evidence of the danger of this corn variety has been found. And now only the ECJ decision established that the EU rules on the circulation of GMO food and GMO feed should ensure "a high level of protection of human health and the smooth functioning of the internal market". Consequently, in the opinion of high judges, it is possible to completely ban GMO products only in one case - If there is conclusive evidence of their "serious health risk".

Computational selection which in the near future may replace genetically modified products and biotechnologies is becoming a promising area of legal regulation. Computational selection makes it possible to produce promising plant varieties without resorting to genetic modification using only sensor information and artificial intelligence algorithms [14].

\section{Conclusion}

This practice of the ECtHR, in our view, very eloquently testifies to the fact that the right to a favourable environment is a complex legal institution the violation of which is not always and not absolutely associated with the violation of the right to life and health. From a human rights perspective, the right to a healthy and quality environment is a fundamental right whose nature and characteristics do not change over time. The case law of the European Court of Human Rights is as follows:

1. The right to a favourable environment, the right to information on its state and environmental challenges, the right to compensation in case of injury may be subject to protection in international judicial institutions, for example, the ECtHR, and violations of these rights are the subject to complaint.

2. Article 8 of the 1950 Convention for the Protection of Human Rights and Fundamental Freedoms is the main rule invoked by the complainants and which the ECtHR applies in "environmental cases". Although the state is not always directly responsible for a specific violation, it can still be a respondent. Inaction on the part of public authorities and the failure to take all possible (not only mandatory) measures to eliminate or prevent an environmental threat that interferes with privacy is enough. However, as the ECtHR has repeatedly emphasized, a state cannot be obliged and responsible for the refusal to relocate citizens to an environmentally sound location or in a monetary payment for this purpose. Environmental problems can arise from state infrastructure projects but such projects have a public interest that is generally above private. However, it is important to balance interests, to inform and engage citizens in the discussion of projects participate in them, try to minimize possible harm.

3. Cases of environmental rights violation are difficult in terms of complaint preparation and handling before the ECtHR. Most of the evidence can only be obtained from public authorities and such information and documents are not always provided or leave doubts about the reliability. Harm to life or health is not difficult to prove but it is difficult to do so with regard to the causal link between the acts (omission) of state bodies, violation of environmental rights and the consequences that have occurred. 
4. Taking into account the priority of health and the environment, the European Union has adopted acts regulating the closed use and deliberate release of GMOs into the environment, their traceability and labelling of products and feed containing GMOs.

5. Since environmental rights are not directly enshrined in the Convention each specific situation and its circumstances require a purely individual approach to consideration and qualification. It is easier when there have already been precedents. They are mainly used in the preparation of complaints. The cases are very complicated if their circumstances do not resemble the cases that have already been considered by the ECtHR.

6. The European experience of ethical and legal regulation of the use of GMOs shows that the bio- and ecocentric attitude is gaining a huge influence. This is causing widespread adoption of the Precautionary Principle. For example, the European Directive «On the deliberate release into the environment of genetically modified organisms» especially emphasized the implementation of precautionary measures. The cumulative nature of the risk is quite justified, even if the likelihood of ecocide [15] as a result of the introduction of a separate GM variety is very small, since «successive multiple attempts to create GMOs can significantly increase this risk» [16].

Part of this research conducted by the co-author of the article is Trikoz Elena, has been supported by RFBR (the project No. 18-29-14100-мк).

\section{References}

1. A. Guterres, Secretary-General's address at Columbia University: "The State of the Planet" (2020) URL: https://www.un.org/sg/en/content/sg/speeches/2020-1202/address-columbia-university-the-state-of-the-planet, last accessed 2021/01/02

2. Draft International Covenant on Environment and Development - Implementing Sustainability (Fifth Edition: Updated Text, 2015) URL: https://sustainabledevelopment.un.org/, last accessed 2021/01/02

3. K. Vasak, The specific problems of the implementation of economic and social human rights. Catholic University of. Center for European Studies. Towards effective protection of economic and social rights. Second colloquium of the Department of Human Rights. Louvian, Vander, 11-34 (1973)

4. Convention for the Protection of Human Rights and Fundamental Freedoms (as amended by Protocols No. 11 and No. 14. Rome, 1950) URL: https://www.echr.coe.int/Documents/Collection_Convention_1950_ENG.pdf, last accessed 2021/01/02

5. Charter of Fundamental Rights of the European Union (2000/C 364/01) URL: https://www.europarl.europa.eu/charter/pdf/text_en.pdf, last accessed 2021/01/02

6. M.-C. Cordonier Segger, Y. Saito, C.G. Weeramantry, Sustainable Development Principles in the Decisions of International Courts and Tribunals: 1992 - 2012, Routledge (2017)

7. Transforming our world: the 2030 Agenda for Sustainable Development UN General Assembly (2015) // UN Doc. A/RES/70/1

8. A. Malinovsky, D. Osina, E. Trikoz, Legal instruments for stimulating environmentally friendly behavior: successful practices in Russia and abroad, E3S Web of Conferences 164, 11039 (2020) DOI: https://doi.org/10.1051/e3sconf/202016411039

9. European Commission. Questions and answers on the regulation of GMOs in the EU (Memo/02/160-REV), Brussels (2003) 
10. A. Kym, A.J. Lee, Why Are US and EU Policies Toward GMOs So Different? AgBioForum 6(3) (2003)

11. V. Denisenko, E. Trikoz, Biopolitics and legal issues of emergency situations in the context of coronavirus pandemic, E3S Web of Conferences 175, 14013 (2020) doi: https://doi.org/10.1051/e3sconf/202017514013

12. J. Davison, GM plants: Science, politics and EC regulations, Plant Science 178(2), 9498 (2010) DOI: 10.1016/j.plantsci.2009.12.005

13. Directive 2001/18/EC of the European Parliament and of the Council of 12 March 2001 on the deliberate release into the environment of genetically modified organisms and repealing Council Directive 90/220/EEC - Commission Declaration, Official Journal of the European Communities 106, 0001-0039 (2001)

14. E. Trikoz, E. Gulyaeva, K. Belyaev, Russian experience of using digital technologies in law and legal risks of AI, E3S Web of Conferences 224, 03005 (2020) DOI: https://doi.org/10.1051/e3sconf/202022403005

15. A. Abashidze, E. Trikoz, The ICC Statute and the Ratification Saga in the States of the Commonwealth of Independent States, International Humanitarian Law Series 19, 1105-1110 (2009)

16. N.N. Taleb, R. Read, R. Douady, J.N.Y. Bar-Yam, The Precautionary Principle (with Application to the Genetic Modification of Organisms), Extreme Risk Initiative - NYU School of Engineering. Working Paper Series. URL: https://arxiv.org/pdf/1410.5787.pdf, last accessed 2021/01/02 